\title{
HISTÓRIA E MÚSICA POPULAR: UM MAPA DE LEITURAS E QUESTÕES
}

\author{
Marcos Napolitano \\ Depto. de História-FFLCH/USP
}

\section{Resumo}

Este artigo traça um roteiro de leituras e questões teórico-metodológicas em torno da reflexão historiográfica sobre a música popular brasileira. Partindo de uma experiência pessoal de formação e pesquisa, aponto tendências de investigação histórica, problemas heurísticos e debates metodológicos que vêm marcando o campo historiográfico da música popular desde os anos 1980. Além de mapear o estado da arte, o artigo sugere novos temas e problemas de trabalho sobre a música brasileira.

\section{Pallavras-Chave}

Música popular: historiografia • História cultural • Música popular: Brasil

\section{Abstract}

This article intends to be a map of the historiographic questions on Brazilian popular music. Based on my personal experience as scholar, I propose research trends, heuristic problems and methodological debates, which characterize the agenda of popular music studies in Brazil since 1980's, from a historiographic perspective. Besides this points, the article proposes further themes and problems to new researches on Brazilian music.

\section{Keywords}

Popular music: historiography • Cultural History • Popular music: Brazil 
Os trabalhos que tratam a música popular como fonte ou objeto têm crescido exponencialmente na área de história, desde os anos 1990. Do ponto de vista acadêmico, este novo tema é tributário das primeiras abordagens da área de letras, sociologia ou antropologia. Ou seja, os estudos sobre música popular têm uma natureza interdisciplinar desde a sua origem. Hoje em dia, além dos historiadores, as áreas de semiótica e comunicação também adensaram este campo de investigação. Presente em vários campos de conhecimento e não pertencendo a nenhum em especial, podemos dizer que a música popular não tem um lugar muito definido nas ciências humanas e artes, fruto do seu próprio estatuto estético um tanto híbrido. Mesmo a musicologia, que normalmente deveria ser o carro-chefe destes estudos, apresenta dificuldades na abordagem das canções veiculadas pelo mercado fonográfico, traduzida na sua tradicional preferência pelos estudos da música erudita e das músicas ditas “folclóricas”. Diga-se, esta dificuldade vem sendo enfrentada nos últimos anos, com a atenção dos musicólogos cada vez mais voltada para as interfaces entre os gêneros comunitários e as formas comerciais de música popular. Em síntese, temos uma situação ao mesmo tempo interessante e desafiadora, na qual os estudos de música popular estão presentes em várias áreas do conhecimento, mas ainda sem estabelecer um olhar entrecruzado que permita dar conta dos seus vários aspectos estéticos, sociológicos e históricos.

Normalmente existem duas formas básicas de abordagem: uma que prioriza um olhar externo à obra e outra que procura suas articulações internas, estruturais. Os campos da história, da sociologia e da comunicação, tendem mais para o primeiro caso. Os campos da semiótica, da musicologia e das letras, tendem mais para a segunda abordagem. Mesmo assim, esta tensão é presente e assumida, mesmo nestes casos bem sucedidos.

Na bibliografia de circulação internacional, o lugar da música popular também é objeto de discussões. A sociologia da música popular vem conseguindo resultados satisfatórios na busca de uma abordagem articulada entre aquela internalista e a externalista. Também vem se esboçando uma "musicologia popular”1 que tenta fazer dialogar as ferramentas de diversas áreas de origem que

\footnotetext{
${ }^{1}$ GONZALEZ, Juan Pablo. "Musicologia popular en América Latina: síntesis de sus logros, problemas y desafios”. Revista M usical Chilena, 195, enero-junio 2001, p. 38-64.
} 
contribuíram para consolidar os estudos de música popular como objeto de conhecimento acadêmico, mas que apresenta dificuldades na abordagem do fenômeno propriamente musical da análise das obras, como é o caso da História. Tanto a musicologia tradicional quanto a etnomusicologia possuem olhares refinados para o campo erudito e folclórico, tradicionais, tendendo para análises formais e estruturais das obras quase sempre ancorada em estruturas melódicoharmônicas e num conceito de performance ligado ao papel tradicional do musicista que dá vida à obra musical, transmitida pela escrita ou pela tradição oral. Justamente, nestes pontos residem os problemas que fazem da canção um objeto não identificado para o olhar musicológico mais tradicional: ela não se define exclusivamente pela natureza estrutural (melódico-harmônica), embora esta seja sua base estética, nem pela performance direta, na qual um musicista ou cantor mobiliza um aparato técnico e organológico ${ }^{2}$ para dar ao ouvinte a experiência da obra musical. Obviamente, estas duas marcas estão presentes na experiência da música popular, constituindo-se na sua base estética mais profunda. Mas as mediações tecnológica e mercadológica colocam desafios novos.

A música popular é fruto de um cruzamento da música ligeira com as músicas tradicionais, das danças de salão com as danças folclóricas. Até aí nenhuma novidade, não fosse o momento histórico que propiciou este encontro, marcado pela expansão da industrialização da cultura e pelo surgimento das sociedades de massa. Portanto, não se trata de um cruzamento simples, de descendência direta, mas de uma filha bastarda, um "logro" recalcado da experiência cultural moderna como escreveu José Miguel Wisnik³. Há também outros aspectos que desafiam o olhar musicológico mais estabelecido.

A música popular, sobretudo na sua manifestação específica que é a canção registrada em fonograma, não se define unicamente pelos seus atributos estruturais melódico-harmônicos pensados como propriedades internas definidoras de formas e gêneros. A rigor, a forma privilegiada da música popular é a canção, tal como consagrada pela indústria do disco. Embora haja confusão entre “forma” e "gênero" musical, este último conceito é um tanto vago, do ponto de vista musicológico, sendo muito comum a confusão entre estilo,

\footnotetext{
${ }^{2}$ Organologia é a parte da musicologia que estuda e classifica os intrumentos musicais.

${ }^{3}$ WISNIK, José Miguel. "Machado, Maxixe”. Teresa - Revista de Literatura Brasileira. n. 4/5, São Paulo, 2004.
} 
movimentos culturais e formas musicais propriamente ditas, como atestam, por exemplo, as polêmicas sobre a definição de samba, bossa nova e tropicália. Produto mais das convenções e interesses de mercado, o gênero musical não se define apenas pelo parâmetro do "ritmo", como quer um certo senso comum. Trata-se, principalmente, de uma convenção, de um conjunto de propriedades fluidas, constantemente debatidas e redefinidas por uma certa comunidade musical de criadores, empresários, críticos e audiências anônimas ${ }^{4}$. Portanto, para se entender um determinado "gênero" é preciso entender a genealogia de uma determinada experiência musical, em seus aspectos diversos, como canção, como dança, como identidade cultural e como produto comercial revestido de efeitos que vão além da performance direta ${ }^{5}$. Exemplo desta complexidade do conceito de gênero musical é papel do timbre. No caso da música popular, o timbre é obtido por processos industriais e tecnológicos e muitas vezes é apropriado pela audiência como um padrão musical definidor de um determinado gênero ou subgênero (ex. samba, rock).

O problema da performance na música popular fonográfica, também deve ser visto para além do conceito de performance direta. Alguns poderiam questionar a existência desta, pois toda experiência cultural - incluindo-se a performance que dá vida sonora a uma música - é mediada por um conjunto de valores, ritos e redes sócio-culturais. Mas, neste caso, estamos falando de uma performance que coloca entre o musicista e a obra um conjunto de elementos "terceiros”, que escapam às mediações sócio-culturais mais conhecidas pela antropologia, embora estas também estejam presentes. Por exemplo, uma canção veiculada pelo mercado fonográfico mobiliza um aparato tecnológico imenso de execução e registro, um conjunto de profissionais que muitas vezes interferem estruturalmente no resultado da canção, uma série de estratégias de veiculação em circuitos massivos. Todos estes elementos constituem uma dada performance, pensada nos termos da música popular comercial. No limite, a própria audição constitui uma performance ${ }^{6}$, que envolve prazer,

\footnotetext{
${ }^{4}$ FABBRI, Franco. “A theory of musical genres: two applications”. In: TAGG, P.; HORN, D. Popular M usic Perspectives. Goteborg and Exceter, IASPM, 1981, p. 52-81.

${ }^{5}$ FRITH, Simon. Performing rites. Evaluating popular music. Oxford University Press, 1998, p. 81.

${ }^{6}$ Idem, Ibidem, p. 203.
} 
sentido e avaliação sócio-cultural e que se dá em vários níveis: há uma audição de músicos, produtores, críticos e audiências anônimas que marcam os ritos performáticos definidores da experiência musical. Se este fenômeno pode não ser exclusivo da música popular, nela ele se potencializa.

E, finalmente, há um outro problema teórico no campo da música popular, sobretudo na sua expressão como canção: a relação entre a fala e o canto, ou entre a palavra falada e a palavra cantada. Se, tradicionalmente, a música cantada se definia como negação da fala cotidiana, dos acentos da fala coloquial, a canção no universo da música popular foi e é marcada por influxos, entonações e acentos que romperam com esta fronteira. A meu ver, a teoria que melhor abordou este problema é aquela que foi desenvolvida por Luis Tatit, a partir da sua experiência com a semiótica greimasiana e com a própria tradição da canção moderna brasileira, surgida entre os anos 1920 e 19307 ${ }^{7}$. Ou seja, o lado teórico e performático de Tatit, que se encontraram numa instigante teoria da canção, rompe com as dicotomias entre fala e canto, na qual "a voz articulada do intelecto converte-se em expressão do corpo que sente. As inflexões caóticas das entoações, dependentes da sintaxe do texto, ganham periodicidade, sentido próprio e se perpetuam em movimento cíclico com um ritual”. . A teoria de Tatit busca os “elementos comuns” às canções, portanto, tenta atingir as propriedades de uma arquicanção, definida como um conjunto dos traços e processos comuns às canções, a partir da neutralização dos traços específicos que contém entre si $^{9}$.

Portanto, o estágio atual dos estudos de música popular é marcado por uma pluralidade de abordagens e problemas que, cada vez mais, precisam ser bem delimitados e cotejados, para que a abordagem não caia no ecletismo teórico ou na reiteração de questões já estabelecidas pelas disciplinas tradicionais e assentadas. Para a área de história, esta preocupação é particularmente importante, pois, sendo aberta às mais variadas influências teóricas e objetos de pesquisa, facilmente pode diluir sua abordagem específica, com o agravante de utilizar os instrumentos e modelos teóricos de origem de maneira enviesada. Isto, para não dizer que os mais céticos duvidam da existência de uma abor-

\footnotetext{
${ }^{7}$ TATIT, Luis. 0 cancionista. Composição de canções no Brasil. São Paulo: Edusp, 1995. ${ }^{8}$ Idem, Ibidem, p. 15.

${ }^{9}$ Idem, Ibidem, p. 26.
} 
dagem historiográfica específica, ainda mais se tratando de um objeto tão híbrido, como é a música popular.

Neste sentido, é que vamos tentar, ao longo das próximas páginas, pensar o que seria uma abordagem especificamente historiográfica da música popular, fruto mais da nossa experiência e das inquietações como pesquisador do que de uma reflexão sistematizada e conclusiva.

\section{II}

Tradicionalmente, falar em história da música significava articular uma narrativa que desse conta, na sucessão do tempo, de autores-obras-movimentos musicais. Leia-se: autores considerados gênios criadores, obras consideradas obras primas e movimentos relevantes para a história da cultura e da sociedade. O material trabalhado pelos historiadores, sejam fontes primárias ou secundárias, muitas vezes era produto de memorialistas e cronistas, historiadores não acadêmicos, que legaram narrativas clássicas da história da música popular brasileira ${ }^{10}$.

No campo de estudos acadêmicos existiam duas abordagens iniciais, construídas ainda no final da década de 1960: a área de letras, mais preocupada com a forma e o sentido dos discursos poéticos das canções; a área de sociologia, mais voltada para a análise dos circuitos, sobretudo os circuitos industriais e comerciais, que marcavam a canção como experiência social. Por outro lado, os musicólogos e memorialistas tinham se concentrado no estudo das formas tradicionais e seminais da música popular brasileira, num olhar frequentemente marcado pela busca das origens, dos gêneros matrizes e das raízes folclóricas. O autor que articulou estas duas tradições, à base de uma crítica pessoal e política aos efeitos da modernidade musical brasileira, foi José Ramos Tinhorão. Em seus trabalhos historiográficos, realizados a partir dos anos 1970, Tinhorão deu continuidade à sua crítica às expropriações culturais dos compositores de classe média em relação aos gêneros de origem popular (sobretudo, choro e samba $)^{11}$. Dono de um vasto acervo documental, os trabalhos de

\footnotetext{
${ }^{10}$ MORAES, J. G. Vinci. "História e Música: a canção popular e o conhecimento histórico”. Revista Brasileira de História, São Paulo, v. 20, n. 39, 2000, p. 203-221; NAPOLITANO, Marcos. H istória e Música. H istória cultural da música popular. Belo Horizonte: Ed. Autêntica, 2002. ${ }^{11}$ Destacamos, entre eles: TINHORÃO, José Ramos. Pequena História da Música PopuIar. São Paulo: Art Editora, 1991, 6ª ed.; M úsica popular: do gramofone ao rádio e TV. São Paulo: Ática, 1981.
} 
Tinhorão mesclam nacionalismo xenófobo com folclorismo de esquerda, cujo criticismo é voltado, principalmente, contra a bossa nova e a MPB dos anos 1960.

Quando a historiografia renovada da música começou a tomar forma e se expandir nos programa de pós-graduação, no final dos anos 1980, o contexto era marcado por um legado forte da área de letras (busca da forma e do sentido poético das canções), sociologia (crítica aos padrões de mercado, normalmente com base adorniana) e por uma história da música popular que buscava as origens, o momento mais autêntico da tradição ${ }^{12}$. Do ponto de vista metodológico, pautava-se por uma mistura de narrativa linear e tradicional (sucessão de obras, autores, gêneros e movimentos) e por um marxismo mais ou menos mecanicista. No caso de Tinhorão, o sócio-econômico determinava o sentido da cultura. Nas abordagens mais adornianas, a indústria cultural, por trás da música popular, era o verdadeiro objeto a ser analisado.

Os estudos sobre música popular brasileira se concentravam em alguns temas privilegiados e consagrados, enquanto outros temas, abordagens e fontes permaneciam praticamente inéditos ou pouco explorados. Na área de ciências humanas há, nitidamente, um debate concentrado em dois objetos: a MPB dos anos 1960 e o Samba. Esta tendência se repete nos títulos de biografias e crônicas jornalísticas.

As relações entre samba, ufanismo conservador e nacionalismo dos anos 1930/40 encontraram um trabalho pioneiro na dissertação de Antonio Pedro Tota $^{13}$. Antes disso, os trabalhos de Sérgio Cabral ${ }^{14}$, Miriam Goldwasser e Ana Maria Rodrigues ${ }^{15}$ já tinham apontado elementos básicos da história do samba e das escolas de samba, seja fruto dos depoimentos dos protagonistas ou da pesquisa participante dentro do universo das escolas de samba do Rio de Janeiro. Na mesma época, a FUNARTE iniciou uma série de biografias de sambistas

\footnotetext{
${ }^{12}$ WASSERMAN, Maria Clara. Abre as cortinas do passado: a Revista de Música Popular e o pensamento folclorista. Rio de Janeiro, 1954-56. Dissertação de Mestrado, História/ UFPR, Curitiba, 2002.

${ }^{13}$ TOTA, Antonio Pedro. 0 samba da legitimidade. Dissertação de Mestrado, História, FFLCH/USP, 1980.

${ }^{14}$ CABRAL, Sérgio. As E scolas de Samba - o que, quem, onde, como, quando e porque. Rio de Janeiro: Funarte, 1974.

${ }^{15}$ GOLDWASSER, Miriam. 0 palácio do samba. Rio de Janeiro: Zahar, 1975; RODRIGUES, Ana Maria. Samba negro, espoliação branca. São Paulo: Hucitec, 1984.
} 
consagrados, reunindo dados sobre a vida e a obra dos compositores da chamada época de ouro (anos 30 e 40). O livro de Roberto Moura ${ }^{16}$ consolidou e disseminou um conjunto de narrativas dos pioneiros do samba - Pixinguinha, Donga, Heitor dos Prazeres - demonstrando o caldo cultural que veio dar no moderno samba carioca. Em relação à MPB, a área de letras deu o tom inicial das abordagens, nos trabalhos de Afonso Romano Sant'anna ${ }^{17}$, nas teses e dissertações produzidas na PUC-RJ ${ }^{18}$ e no trabalho de Adélia Meneses sobre Chico Buarque $^{19}$. Estes trabalhos, com ênfase na expressão poética das canções de MPB, foram modelos de abordagem que muito influenciaram os primeiros trabalhos de História. Ainda nos anos 1970, Celso Favaretto lançava seu trabalho clássico sobre a Tropicália ${ }^{20}$, explorando a articulação entre a análise das obras sob o ponto de vista da alegoria poética e da crítica cultural, na perspectiva da vanguarda, seguindo as pistas do seminal Balanço da Bossa, coletânea-manifesto de Augusto de Campos publicada na década anterior.

Enquanto isso, a área de sociologia começava a desenvolver trabalhos sobre os circuitos e agentes sociais do samba e da $\mathrm{MPB}^{21}$. O tema do mercado fonográfico, em sua gênese (samba) ou em sua maturidade (MPB), foi objeto de reflexão e passou a fazer parte da agenda dos pesquisadores, ainda sem um grau de aprofundamento heurístico ou teórico que pudesse escapar dos grandes modelos herdados da teoria adorniana, da "indústria cultural”.

Neste contexto formativo de um olhar acadêmico sobre a música popular, merecem destaque dois autores que, de uma maneira ou de outra, inovaram as perspectivas deste campo, cruzando o princípio da descontinuidade histórica com o princípio da obra de arte como mímese das tensões e contradições sociais. São eles, Arnaldo Contier e José Miguel Wisnik. Ambos, originalmente,

\footnotetext{
${ }^{16}$ MOURA, Roberto. A Casa da Tia Ciata e a Pequena África do Rio de Janeiro. Rio de Janeiro: Funarte, 1983.

${ }^{17}$ SANT’ANNA, Afonso R. M úsica popular e moderna poesia brasileira. Petrópolis: Vozes, 1974.

${ }^{18}$ MATOS, Cláudia. Acertei no milhar: samba e malandragem no tempo de G etúlio. Rio de Janeiro: Paz e Terra, 1982; BORGES, Beatriz. Samba-canção:fratura e paixão. Rio de Janeiro: Codecri, 1982.

${ }^{19}$ MENESES, Adélia. Desenho mágico: poesia e política em Chico Buarque. São Paulo: Hucitec, 1982.

${ }^{20}$ FAVARETTO, Celso. Tropicália: alegoria, alegria. São Paulo: Kairós, 1979.

${ }^{21}$ CALDEIRA, Jorge. A voz macia: o samba como padrão da música popular brasileira. Dissertação de Mestrado, Sociologia, FFLCH/USP, 1987.
} 
trabalharam com o campo da música erudita ${ }^{22}$, mas inovaram ao pensar a história da música brasileira para além desta dicotomia. Os trabalhos de ambos, sobre a vanguarda musical dos anos 1920/1930, apontavam para uma conexão inovadora entre estética e ideologia e, ressalvadas as diferenças de objeto e abordagens, o que se pode dizer é que, do ponto de vista metodológico, ambos exploravam as tensões e contradições entre projeto autoral, fatura estética e circulação sócio-cultural. O problema da identidade nacional se colocava de maneira dialética, sem os vícios nacionalistas da historiografia tradicional (Renato Almeida, Vasco Mariz, Oneyda Alvarenga).

Na virada da década de 1990, Arnaldo Contier apontou para outras possibilidades da história da música. Com base em concorridos cursos e alguns textos teóricos ${ }^{23}$, Contier estabeleceu novas possibilidades para uma história da música, para além da dicotomia popular versus erudito. Entre os princípios metodológicos, que muito influenciaram meu trabalho de doutorado, destacam-se:

a) O princípio da descontinuidade histórica e a crítica das origens.

b) Tensão entre a memória canônica e a história crítica, frequentemente cotejadas no mesmo trabalho historiográfico.

c) Valorização da experiência da escuta como método de análise da canção. A escuta de quem escreveu sobre a história da música; a escuta do pesquisador que busca romper com o legado historiográfico; a escuta do próprio performer da canção.

d) A valorização de uma tensão básica, a qual deveria ser explorada criticamente, a saber: a história da música como organização dos sons com base em princípios estéticos, confrontada com a história do pensamento sobre a música, com base no conceito de "escuta ideológica".

Num certo sentido, a abordagem proposta nos cursos de Arnaldo Contier radicalizava a questão da performance como marca de uma diacronia radical, seja esta a do músico que executa, seja como escuta em si mesma. Outro ponto

\footnotetext{
${ }^{22}$ CONTIER, Arnaldo. Brasil Novo: música, nação e modernidade. Tese Livre Docência, FFLCH/USP, 1988; WISNIK, José Miguel. 0 coro dos contrários. M úsica em torno da Semana de 22. São Paulo: Duas Cidades, 1977.

${ }^{23}$ Entre eles, destacamos: CONTIER, A. D. "Música no Brasil: História e Interdisciplinalidade. Algumas Interpretações (1926-1980)”. In: CONTIER, Arnaldo (org.). H istória em D ebate. São Paulo: ANPUH/CNPq, 1991, v. 1, p. 151-189.
} 
instigante do seu método é que crítica historiográfica e crítica da memória social se interpenetravam na descontrução de objetos e explicações monolíticas, herdadas do "estado da arte" sobre a música.

A partir destas premissas teorico-metodológicas, a abordagem da história da música (e da história da arte, como um todo) ganhou novas possibilidades, entre elas, a exploração das tensões advindas da análise crítica da obra, das falas sobre a obra e das redes de influências e filiações estéticas e intelectuais. Estas, aliás, estavam mais próximas das estratégias de legitimação dos atores e sujeitos históricos, do que de uma efetiva historicidade da obra e do artista num determinado tempo e espaço. Tratava-se, portanto, de assumir o jogo entre documento e monumento como central para a análise histórica das canções. A historiografia da música popular, pelo seu caráter meio enjeitado, se sentiu mais à vontade para operar estas novidades metodológicas, explorando a polifonia das experiências musicais como parte da história de uma sociedade.

No caso de José Miguel Wisnik, desde o final dos anos 1970 seus textos sobre música popular apontavam para uma nova forma de pensar a relação entre música, sociedade e ideologia, numa perspectiva em que a obra de arte não era mero reflexo das estruturas sociais, nem expressão direta da história das idéias e das ideologias. A obra, nesta perspectiva, era uma espécie de feixe de tensões de problemas e de séries culturais, muitas vezes contraditórias e, por isso mesmo, expressão dos projetos e lutas culturais de uma determinada época. Estas questões não apenas poderiam ser vislumbradas nas letras das canções, mas na sua estrutura propriamente musical e na performance.

Enfim, no início dos anos 1990, as abordagens acadêmicas da música popular já tinham uma história e um adensamento significativo, muito embora houvesse objetos e fontes inéditas a explorar.

Em primeiro lugar, já era possível perceber um objeto histórico consagrado, marcado pelo eixo "Samba-MPB" como o mainstream das reflexões e escolhas de objetos, com algum destaque para a Tropicália e para a Bossa Nova, que entrariam para a agenda de pesquisa de uma vez por todas a partir da segunda metade da década. Cada vez mais, os estudos tentavam ir além da análise centrada na poética ou nos elementos biográficos e contextuais, na direção de uma análise que passava a levar em conta a obra como um todo (as canções e sonoridade dos gêneros musicais), por sua vez, vista por uma perspectiva que tentava ir além da análise formal ou técnico-estética. Do ponto de vista teórico, apontava-se para a necessidade de uma superação do determinismo economicista (arte como reflexo da sociedade), da linearidade histórica (arte 
como sucessão cumulativa de eventos interligados e linhagens de criação estética), das hierarquias sócio-culturais (história da arte como sucessão de obras primas e gênios). Outra indicação era a relação mais sutil entre expressão artística e projetos ideológicos, com mediações de diversas ordens: estéticas, comerciais, identitárias.

A geração de historiadores que fez parte do primeiro boom de trabalhos acadêmicos sobre música popular, na virada dos anos 1980 para os anos 1990, de uma forma ou de outra, passou a desenvolver suas pesquisas tendo como balizas estas questões, as quais acabaram por ser adensadas por outros problemas teórico-metodológicos. Os trabalhos de Carlos Alberto Zeron, sobre a musica de vanguarda brasileira dos anos 1960-80, de José Geraldo Vinci, sobre as relações entre música e história cultural da cidade, de Enor Paiano, sobre as hierarquias sócio-culturais da música popular e o meu próprio, sobre a gênese da MPB e os festivais, traziam as marcas destes novos problemas propostos no final da década anterior ${ }^{24}$.

Na década de 1990, também assistimos a consolidação de uma teoria da canção ${ }^{25}$, com base na semiótica, articulando fala e canto numa perspectiva inovadora que apontava para a integração da palavra e da melodia, como base dos significados básicos veiculados pela “dicção” do cancionista. Numa perspectiva mais historiográfica, iniciou-se a exploração de novos temas monográficos, numa clara revisão dos temas consagrados pelos memorialistas e cronistas da música popular. A historiografia e a antropologia passaram a investir na crítica às hierarquias estéticas consagradas, explorando a genealogia dos valores que marcam o processo de legitimação da canção como objeto cultural. Neste sentido, contribuíram trabalhos marcantes que revisaram a forma com que gêneros musicais eram situados historicamente, como pode-

\footnotetext{
${ }^{24}$ ZERON, Carlos A. F undamentos histórico-políticos da M úsica N ova e da música engajada no Brasil a partir de 1962: 0 salto do tigre de papel. Dissertação de Mestrado, História, FFLCH/USP, 1991; MORAES, José G. Vinci. Sinfonia na M etrópole. História, Cultura e M úsica Popular em São Paulo (Anos 30). Tese de Doutorado, História, FFLCH/USP, 1998; PAIANO, Enor. 0 B erimbau e o som universal. Dissertação de Mestrado, Comunicação Social, ECA/USP, 1991; NAPOLITANO, Marcos. Seguindo a canção: engajamento político e indústria cultural na M PB - 1959-1969. Tese de Doutorado, História, FFLCH/USP, 1999.
}

${ }^{25}$ TATIT, Luis. 0 cancionista. 0 p.cit. 
mos ver no caso da canção brega ${ }^{26}$, na bossa nova ${ }^{27}$ e mesmo em relação ao samba, em dois trabalhos que articulam o historiográfico ao antropológico ${ }^{28} \mathrm{e}$ que apontaram novos rumos para pensar o samba. Outro tema que ganhou a academia foi o estudo detalhado do mercado fonográfico, em suas formas, circuitos e estruturas, para além dos modelos teóricos abstratos, sem, no entanto, abrir mão destes, cujos exemplos vemos no trabalho sobre a indústria fonográfica de Márcia Tosta Dias e Camila Koshiba ${ }^{29}$.

O campo das biografias e memórias ganhou novo fôlego com trabalhos de cunho jornalístico sobre eventos, gêneros e autores, que revelaram novos detalhes a partir da incorporação de novas memórias, depoimentos inéditos e fontes de época. Neste sentido, destacamos os trabalhos de Luiz Antonio Giron sobre Mário Reis, Homem de Mello sobre os festivais da canção e Nepomuceno sobre a música caipira, todos da editora $34^{30}$. Um bom exemplo de cruzamento de revisão biográfica com análise histórica pode ser visto nos trabalhos de Tânia Garcia sobre Carmem Miranda e Márcia Oliveira sobre Lupicínio Rodrigues ${ }^{31}$.

E, finalmente, outro legado da década de 1990, foi a consagração da Tropicália como tema standard de pesquisa, a partir de diversos enfoques: narração detalhada dos eventos e personagens do movimento ${ }^{32}$, a análise como

\footnotetext{
${ }^{26}$ ARAUJO, Paulo Cesar. Eu não sou cachorro, não! M úsica Popular Brega e Ditadura M ilitar. Rio de Janeiro: Civilização Brasileira, 2001.

${ }^{27}$ GARCIA, Walter. Bim Bom: a contradição sem conflitos de J oão G ilberto. São Paulo: Paz e Terra, 1999.

${ }^{28}$ VIANNA, Hermano. 0 mistério do samba. Rio de Janeiro: Jorge Zahar Editor, 1995; SANDRONI, Carlos. Feitiço decente: transformações do samba no Rio de J aneiro, 19171933. Rio de Janeiro: Jorge Zahar Editor, 1997.

${ }^{29}$ DIAS, Marcia Tosta. O s donos da voz: indústria fonográfica brasileira e mundialização da cultura. São Paulo: Boitempo Editorial, 1999; GONÇALVES, Camila Koshiba. M úsica em 78 rotações: 'discos a todos os preços' na São Paulo dos anos 30. Dissertação de Mestrado, História, FFLCH/USP, 2006.

${ }^{30}$ GIRON, Luz A. Mário Reis: o fino do samba. São Paulo: Ed. 34, 2001; HOMEM DE MELLO, Zuza. A era dos festivais: uma parábola. São Paulo: Ed. 34, 2003; NEPOMUCENO, Rosa. M úsica Caipira. Da roça ao rodeio. São Paulo: Ed. 34, 1999.

${ }^{31}$ GARCIA, Tânia. 0 it verde-amarelo de Carmem M iranda. São Paulo: Annablume, 2004; OLIVEIRA, Marcia. U ma leitura histórica da produção musical do compositor Lupicínio Rodrigues. Tese de Doutorado, História, UFRGS, 2002.

${ }^{32}$ CALADO, Carlos. Tropicália: a história de uma revolução musical. São Paulo: Ed. 34, 1997.
} 
vanguarda musical ou cultural ${ }^{33}$ e trabalhos monográficos sobre personagens menos estudados, como Duprat, Tom Zé e Torquato Neto.

\section{III}

À medida que a ênfase no discurso literário que é veiculado na canção, marca dos primeiros estudos de música popular no Brasil, deixou de dar o tom aos trabalhos historiográficos mais importantes, um novo vácuo metodológico se estabeleceu. A teoria da semiótica da canção se apresentou como opção teoricamente coerente e articulada, mas, num certo sentido, enfrenta a resistência de alguns historiadores, pela ênfase na análise sincrônica e pelos limites do conceito de "dicção" para dar conta da dinâmica da historicidade da canção - como objeto cultural que ganha sentido a partir de audiências e de aspectos não musicais (performance, gesto, mediação tecnológica, publicidade, etc). Portanto, qualquer historiador que quisesse ir além de uma história literária ou intelectual da canção, ou ao menos, quisesse articular estes dois importantes aspectos à análise da obra musical, teria que se apropriar de novas ferramentas teóricas para tal empreitada. Dois campos de conhecimento tem se destacado neste sentido: a sociologia da música e a musicologia. Evidentemente, não se pode negligenciar o papel da antropologia que seja mais ligada ao recorte histórico ${ }^{34}$, ao trabalho de campo com sub-culturas juvenis de corte identitário apoiado na música ${ }^{35}$, ou mais ligada à etnomusicologia renovada ${ }^{36}$. Estes trabalhos de recorte sociológico ou antropológico também vêm fornecendo importantes reflexões aos estudos musicais, renovando a perspectiva que une música e identidade. Se o diálogo entre historiadores e antropólogos, até pela importância que a área teve na afirmação de algumas vertentes de história

\footnotetext{
${ }^{33}$ VILLAÇA, Mariana Martins. Polifonia Tropical: experimentalismo e engajamento na música popular (B rasil e em C uba ,1967-1972). São Paulo: Humanitas/FFLCH-USP, 2003; DUNN, Chistopher. Brutality Garden. Tropicalia and the Emergence of a Brazilian C ounterculture. Chapel Hill, NC: University of North Carolina Press, 2001.

${ }^{34}$ NAVES, Santusa. 0 violão azul. Rio de Janeiro: FGV, 1998.

${ }^{35}$ VIANNA, Hermano. 0 mundo funk carioca. Rio de Janeiro: Jorge Zahar Ed., 1988; HERSCHMANN, Micael. O funk e hip hop inva dem a cena. Rio de Janeiro: Ed. UFRJ, 2000. ${ }^{36}$ SANDRONI, Carlos. O p.cit.; DE PAULA, Allan. 0 tronco da roseira: por uma antropologia da viola caipira. Dissertação de Mestrado, Antropologia, UFSC, Florianópolis, 2004.
} 
cultural, tem sido mais comum, o diálogo entre historiadores e sociólogos, e musicólogos ainda é muito incipiente.

Autores bem conhecidos no exterior como Simon Frith, Richard Middleton e Keith Negus ainda não tiveram seus livros e artigos traduzidos ${ }^{37}$. Mesmo as publicações originais começaram a ser conhecidas a partir do final do século XX, quando as principais obras destes autores já circulavam havia algum tempo. A grande contribuição desta corrente foi privilegiar a análise do "texto performativo gravado, considerando os níveis de significado que adquirem a letra de uma canção a ser cantada - devido a fatores de timbre, expressão, respiração, gestualidade e modelagem (grain) - e suas transformações rítmicas, melódicas e de coloração harmônica ao ser interpretada e mixada num estúdio de gravação"38. Além disso, eles são mais abertos ao estudo das canções, autores e gêneros não canônicos, não legitimados na hierarquia de valores sócio-culturais. Na ótica destes autores, mesmo a canção estandardizada, catalogada como "comercial, impura, simplória e corporal”39, tem algo a dizer sobre a sociedade e sobre os sujeitos que a consomem, nem sempre apenas pelo viés da “alienação”, como quer a tradição adorniana, ainda muito presente no meio acadêmico brasileiro.

Neste ponto encontra-se uma das primeiras dificuldades, pois os estudos musicais no Brasil, tradicionalmente, estão ligados ao processo de legitimação sóciocultural do objeto estudado, como se apenas os gênios e obras-primas pudessem informar sobre as relações entre música, história e sociedade. Obviamente, a interação de segmentos da elite cultural e da cultura letrada com a música popular urbana e seus grupos sociais originários é uma marca muito forte no Brasil e explica esta tendência. Por outro lado, é inegável que nem sempre a obra prima e o gênio explicam o lugar social e histórico da música popular nas sociedades de massa. As músicas para dança, os clichês poéticos, os padrões melódico-harmônicos simplificados também informam sobre o imaginário, valores sociais, preconceitos e mesmo sobre uma visão de mundo "from below". Neste sentido, entre nós, apenas mais recentemente os trabalhos historiográficos têm se voltado para fenômenos musicais não legitimados, como o estudo da música popular cafona de Paulo

${ }^{37}$ FRITH, S. O p.cit; NEGUS, Keith. Popular M usic in Theory. Polity Press, 1996; MIDDLETON, Richard. Studying Popular M usic. Open University Press, 1990.

${ }^{38}$ GONZALEZ, J. Pablo. Op.cit., p. 48.

${ }^{39}$ Idem, ibidem. 
César Araujo. Entretanto, alguns destes trabalhos tentam questionar a hierarquia de valores, pela estratégia de apontar valores críticos, canônicos ou positivos não vislumbrados anteriormente apenas por preconceito dos pesquisadores - nestes gêneros e autores marcados pela mediocridade musical e poética. Ou seja, apesar da emergência destes novos temas, ainda é preciso separar de maneira mais clara o estudo sociológico e histórico da música popular das demandas por legitimação do objeto na hierarquia sócio-cultural vigente numa dada época. Em outras palavras, ainda precisamos aprimorar a perspectiva - musicológica, sociológica e histórica - que analise a obra prima e a obra medíocre de maneira articulada, como expressões de uma mesma forma musical, em si considerada menor pelos cânones eruditos herdados do século XIX, que é a canção (ou as músicas dançantes como um todo). Por exemplo, não se trata de "igualar” Chico Buarque e Odair José do ponto de vista da importância política, do talento literário ou musical, mas de entender como a cena musical brasileira fez conviver, sob o signo do disco e da canção, os dois compositores num mesmo contexto e quais as expressões culturais e imaginários sociais a eles vinculadas. Por outro lado, a grande contribuição dos historiadores, neste sentido, seria entender criticamente o processo histórico de legitimação sócio-cultural de autores, gêneros e obras, necessariamente diacrônico, marcado por descontinuidades, monumentalizações, lugares de memória e invenção de tradições ${ }^{40}$.

Em relação à musicologia, o diálogo é mais difícil, mas tem sido aprofundado nos últimos anos. Tradicionalmente, o campo da musicologia se estabeleceu privilegiando as formas eruditas e canônicas (musicologia histórica) ou as formas musicais anônimas e comunitárias (etnomusicologia). A música popular comercial e urbana não teve um lugar privilegiado, a não ser os gêneros que estiveram ligados à construção das identidades nacionais do século XX, como o samba, a rumba, o jazz, o tango. Assim mesmo, estes gêneros eram estudados pelos musicólogos mais preocupados com a delimitação de origens, filiações e práticas coletivas, evitando-se o enfoque sobre os aspectos autorais, massivos e industrializados que marcaram a história destes. Nos últimos anos, muitos musicólogos têm ampliado as abordagens tradicionais, seja reclamando a necessidade de uma "musicologia popular" voltada para o estu-

\footnotetext{
${ }^{40}$ NAPOLITANO, Marcos. A síncope das idéias: a questão da tradição na música popular brasileira. São Paulo: Editora Fundação Perseu Abramo, 2007.
} 
do da música popular urbana, mediatizada, massiva e moderna, seja mesclando a abordagem musicológica com a abordagem de problemas e categorias mais amplas ${ }^{41}$.

As dificuldades e resistências não são poucas, pois algumas práticas assentadas da musicologia estão sendo questionadas, tais como: a) a transcrição feita pelo observador do fenômeno musical; b) a desconsideração das mediações técnicas e tecnológicas na performance, gravação, circulação; c) o papel da audiência na negociação dos sentidos e formas (gêneros) que a canção assume, muitas vezes definidas sem muita ligação com aspectos musicológicos estritos. A ênfase na análise formal e harmônica do fato musical, na musicologia tradicional, revela a carência de uma teoria do ritmo que seja adequada à música popular comercial, cujo resultado acaba por "reduzir à escritura fenômenos rítmicos ligados à performance, como a antecipação do ataque, a rítmica aditiva, a irregularidade métrica e a polirritmia corporal”42.

Por outro lado, muitas partituras de canções ou peças instrumentais qualificadas no campo da música popular são transcrições simples e ligeiras de estruturas harmônicas básicas e linhas de voz, não permitindo uma análise mais ampla da mesma canção, quase sempre mais complexa quando se ouve, não apenas em termos timbrísticos, mas também pelo papel das improvisações, da entonação e dos efeitos vocais, das ferramentas de intervenção técnica (corte, mixagem, equalização, grau de homogeneização sonora). Portanto, boa parte da experiência da música popular é basicamente um fenômeno social que acontece mediante o registro sonoro (fonograma) e suas interferências na composição do resultado final do que se ouve. O fonograma, no Brasil, é uma tecnologia que data de 1902, mas ainda possui poucos estudos específicos. Além disso, como documentação histórica e musicológica ainda carece de uma teorização consistente ${ }^{43}$ que permita desenvolver uma análise formal, performática e histórica, na medida que todo fonograma traz a marca de uma época, seu estágio técnico e seu mundo sonoro. Talvez, esta seja a grande contribuição das parcerias desta nova musicologia com a historiografia.

\footnotetext{
${ }^{41}$ IKEDA, Alberto. M úsica política: imanência do social. Tese de Doutorado, Comunicação, ECA/USP, 1995.

${ }^{42}$ GONZALEZ, Juan Pablo. 0 p.cit., p. 51.

${ }^{43}$ NAPOLITANO, Marcos. "Fontes audiovisuais: a história depois do papel”. In: PINSKY, Carla B. (org.). Fontes H istóricas. São Paulo: Contexto, 2005.
} 
Algumas questões são urgentes, neste sentido. Em primeiro lugar, é preciso refletir sobre o papel do timbre gravado (organológico e vocal) para a definição do gênero, sem falar em outros efeitos da relação acompanhamento/vocalização, como a defasagem, as divisões, os ornamentos. Para o estudo da obra de Elis Regina ou João Gilberto, sob prismas diferenciados, estas questões são fundamentais. Em segundo lugar, como já apontado, a musicologia deve aprofundar a reflexão acerca da articulação orgânica entre harmonia e ritmo, como já sugeriu o instigante estudo sobre o violão de João Gilberto, feito por Walter Garcia $^{44}$. Também não é menos importante a ampliação dos estudos sobre os vários agentes responsáveis pela formatação do produto fonográfico, a saber: o compositor, o intérprete, os instrumentistas, os executivos das gravadoras, o diretor de estúdio, os engenheiros de som, os publicitários e marqueteiros. Este leque de agentes, relacionando-se entre si de maneira quase sempre tensa e negociada, acaba por definir o resultado final da música ouvida. Muitas vezes, a relação entre eles é assimétrica, sobretudo quando os compositores e intérpretes são quadros artísticos pouco legitimados do ponto de vista sócio-cultural, ou dotados de pouca capacidade técnica. Por outro lado, como já definiu Tatit, vivemos na era dos “engenheiros de som”, profissional cada vez mais importante na formatação do produto musical mais estandardizado e de grande circulação.

Pode soar estranho apontar a necessidade de uma teoria do fonograma clássico, num momento em que as regras de gravação estabelecidas desde o início do século XX e seus suportes tradicionais tendem a ser diluídos no mundo digital e das novas tecnologias de comunicação, como o celular e a internet. Entretanto, para o historiador, o fonograma em seus suportes materiais (disco, CD) ainda constitui um material documental enorme, com muito potencial de pesquisa que, aliás, não fosse o trabalho heróico e apaixonado dos colecionadores, já teria desaparecido em grande parte, pois nem as gravadoras, nem o poder público parecem dar valor a eles. Por exemplo, ainda não houve uma iniciativa para catalogar os long plays lançados no Brasil, suporte fonográfico tão fundamental para a história da música popular entre os anos 1950 e 1980. Tal empreitada só poderia ser vencida com a soma dos trabalhos dos pesquisadores acadêmicos, dos colecionadores, das gravadoras e do poder público.

${ }^{44}$ GARCIA, W. Op.cit. 


\section{IV}

Ao final desta primeira década do século XXI, o pós-graduando que se aventurar pelos caminhos que ligam a história à música já encontrará um terreno mais mapeado e com sinalizações seguras e bem posicionadas. Não há mais o preconceito generalizado ou as dúvidas se a música popular é um objeto legítimo ou não para o historiador. Seja como fonte ou como objeto, a música popular pode gerar trabalhos instigantes de história política, econômica, social ou cultural. Pode até ser a base de uma nova história da música, tout court. Os pontos de conexão teórico-metodológica entre as várias áreas que compõem os estudos de música popular estão indicados, embora ainda falte incrementar o diálogo e as trocas efetivas entre elas. Há uma base bibliográfica considerável sobre a canção e a música popular brasileira, na forma de livros, artigos e, sobretudo, teses ainda não publicadas. Os fóruns de discussão interdisciplinares têm crescido, como os encontros de musicologia abertos a pesquisadores de outras áreas, os congressos da IASPM ${ }^{45}$ e os vários eventos sobre música popular mundo afora. A linguística e a semiótica têm refinado seus instrumentos teóricos, bem como a sociologia, ampliando as possibilidades das áreas de letras, história e comunicações. Em que pesem as diferenças de abordagens e modelos teóricos, ainda não foram esgotadas as trocas e intercâmbios entre as ferramentas destas áreas.

Atualmente, para o historiador, o desafio está em ir além dos temas consagrados, tais como, compositores canônicos de MPB, a vanguarda e o movimento tropicalista ou aspectos histórico-sociais do samba. Outros temas demandam pesquisas urgentes: os diversos gêneros pop que marcaram a cena musical brasileira não são suficientemente estudados, tampouco as músicas populares não canônicas ou legitimadas (brega, axé, bolero etc.). Quase nada se sabe sobre temas importantes, tais como: práticas de dança de salão ao longo do século $\mathrm{XX}^{46}$, a formação e ensino musical, a relação entre televisão, cinema e

\footnotetext{
${ }^{45}$ Sigla da International Association for the Study of Popular M usic. O ramo latino-americano foi fundado em 2000 e já realizou sete Congressos em várias cidades do continente. Ver Anais em http://www.hist.puc.cl/iaspm/iaspm.html.

${ }^{46}$ ROCHA, Francisco Alberto. Figurações do Ritmo: da sala de cinema ao salão de baile paulista. Tese de Doutorado, História, FFLCH/USP, 2007.
} 
música popular, os padrões de arranjo instrumental da música brasileira ${ }^{47}$, a crítica musical, o video clip como linguagem audiovisual e musical, o mercado de partituras e dos livretos de cancioneiros. Outro desafio para o historiador, além da ampliação do leque de temas e objetos, é a ampliação do corpus documental que envolve o estudo de música popular. Mesmo no caso de temas clássicos, como a história do samba, do rádio e da MPB, novas fontes podem revelar novos ângulos de abordagem: séries estatísticas, acervos de fã-clubes, revistas de mídia, partituras, contratos de artistas, correspondências, romances e crônicas, fotos, material audiovisual. Enfim, há toda uma tipologia documental que pode ir além do corpus documental mais utilizado nas teses e dissertações (canções, depoimentos pessoais e matérias de imprensa).

Num dos países mais ricos em diversidade sonora do mundo, com um lugar privilegiado na história da música popular do século XX, dedicar-se à história da música, pensada em diálogo com a história intelectual, social, política e cultural, é dar um passo a mais na compreensão da própria sociedade e suas formas de auto-representação. E ainda há muito por fazer.

${ }^{47}$ BESSA, Virgínia de Almeida. U m bocadinho de cada coisa: trajetória e obra de Pixinguinha. História e música popular no Brasil dos anos 20 e 30. Dissertação de Mestrado, História, FFLCH/USP, 2006. 